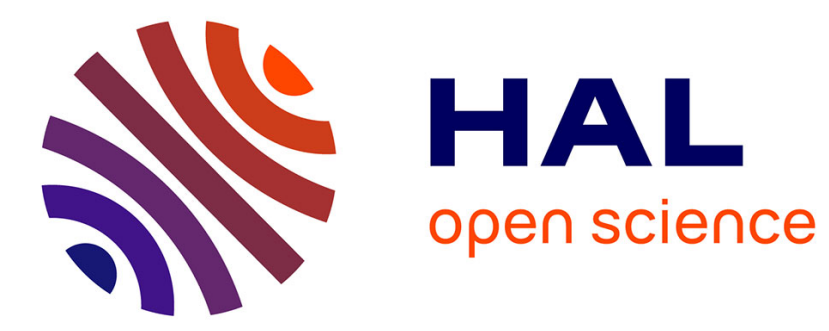

\title{
Slab flattening, magmatism, and surface uplift in the Cordillera Occidental (northern Peru)
}

\author{
Audrey Margirier, Xavier Robert, Laurence Audin, Cécile Gautheron, \\ Matthias Bernet, Sarah Hall, Thibaud Simon-Labric
}

\section{- To cite this version:}

Audrey Margirier, Xavier Robert, Laurence Audin, Cécile Gautheron, Matthias Bernet, et al.. Slab flattening, magmatism, and surface uplift in the Cordillera Occidental (northern Peru). Geology, 2015, 43 (11), pp.1031-1034. 10.1130/G37061.1 . insu-01677064

\section{HAL Id: insu-01677064 https://hal-insu.archives-ouvertes.fr/insu-01677064}

Submitted on 16 Feb 2018

HAL is a multi-disciplinary open access archive for the deposit and dissemination of scientific research documents, whether they are published or not. The documents may come from teaching and research institutions in France or abroad, or from public or private research centers.
L'archive ouverte pluridisciplinaire HAL, est destinée au dépôt et à la diffusion de documents scientifiques de niveau recherche, publiés ou non, émanant des établissements d'enseignement et de recherche français ou étrangers, des laboratoires publics ou privés. 
Publisher: GSA

Journal: GEOL: Geology

DOI:10.1130/G37061.1

\section{Slab flattening, magmatism and surface uplift in the}

\section{Cordillera Occidental (northern Peru)}

3 Audrey Margirier ${ }^{1}$, Xavier Robert ${ }^{1,2}$, Laurence Audin ${ }^{1,2}$, Cécile Gautheron ${ }^{3}$,

4 Matthias Bernet $^{1}$, Sarah Hall ${ }^{4}$, and Thibaud Simon-Labric ${ }^{5}$

$5{ }^{1}$ Université de Grenoble-Alpes, ISTerre, F-38041 Grenoble, France

$6 \quad{ }^{2}$ Institut de recherche pour le développement (IRD), ISTerre, F-38041 Grenoble, France

$7 \quad{ }^{3}$ Université Paris Sud, UMR GEOPS-CNRS 8148, 91405 Orsay, France

$8{ }^{4}$ College of Atlantic, 105 Eden Street, Bar Harbor, Maine 04609, USA

$9 \quad{ }^{5}$ IDYST, University of Lausanne, CH-1015 Lausanne, Switzerland

10 ABSTRACT

11 The impact of subduction processes on surface uplift and relief building in the

12 Andes is not well understood. In northern Peru we have access to a modern flat

13 subduction zone $\left(3-15^{\circ} \mathrm{S}\right)$ where both the geometry and timing of the flattening of the

14 slab are well constrained. Some of the highest Andean peaks, the Cordillera Blanca (6768

$15 \mathrm{~m})$ and the Cordillera Negra $(5187 \mathrm{~m})$, are located just above the Peruvian flat-slab. This

16 is a perfect target to explore the impact of slab flattening and associated magmatism on

17 the Andean topography and uplift. We present new apatite (U-Th)/He and fission-track

18 data from three vertical profiles in the Cordillera Blanca and the Cordillera Negra. Time-

19 temperature inverse modeling of the thermochronological data suggest that regional

20 exhumation in the Cordillera Occidental started at $\sim 15 \mathrm{Ma}$, synchronous with the onset of

21 subduction of the Nazca Ridge and eastward movement of regional magmatism. We

22 propose that ridge subduction at $15 \mathrm{Ma}$ and onset of slab flattening drove regional surface 
Publisher: GSA

Journal: GEOL: Geology

DOI:10.1130/G37061.1

23 uplift, with an important contribution of magmatism to relief building in the Cordillera

24 Occidental.

\section{INTRODUCTION}

26 The Andes are often presented as the classic example of relief building along a

27 non-collisional convergent plate boundary, but many subduction zone processes,

28 specifically related to surface uplift, are still not fully understood. Along the western

29 Andean margin topography and slab dip vary significantly, resulting in a clear

30 segmentation along strike, with two modern flat-slab segments in northern Peru (3-15 $5^{\circ}$;

31 Fig. 1) and central Chile (28-32 ${ }^{\circ}$ S) (Barazangi and Isacks, 1976). These flat-slab

32 subduction zones influence the occurrence and location of magmatic activity along the

33 Andean range with the magmatic arc migrating away from the trench and even ceasing to

34 exist during slab flattening. Slab flattening also increases coupling at the plate interface,

35 resulting in an increase and eastward displacement of shortening in the overriding plate

36 and consequent surface uplift in both the Andean fore-arc and back-arc (e.g., Ramos and

37 Folguera, 2009). However, the impact of slab flattening on surface uplift in the western

38 part of the Andes (Cordillera Occidental) remains unclear.

39 The geometry and timing of slab flattening in northern Peru are constrained by the

40 subduction of two buoyant features, the Nazca Ridge and the Inca Plateau (e.g., Gutscher

41 et al., 1999; Rosenbaum et al., 2005). In this region the Cordillera Blanca (CB), a

42 Miocene batholith exhumed along a $\sim 150 \mathrm{~km}$ long crustal-scale normal fault trending

43 parallel to the range, forms the highest Peruvian peaks (Fig. 1; e.g., McNulty and Farber,

44 2002). In the context of flat subduction, which is expected to produce shortening, the

45 presence of this major normal fault is surprising. Two models have been proposed to 
Publisher: GSA

Journal: GEOL: Geology

DOI:10.1130/G37061.1

46 explain the Cordillera Blanca Normal Fault (CBNF). Dalmayrac and Molnar (1981)

47 suggested that extension was induced by gravitational collapse of a thickened crust,

48 whereas McNulty and Farber (2002) suggested extension due to the arrival of the Nazca

49 Ridge beneath this region, which temporarily increased the coupling with the overriding

50 plate. Understanding the exhumation of the $\mathrm{CB}$ and extension along the CBNF in this

51 compressive regime is important for understanding the impact of ridges and flat

52 subduction on the Andean relief development.

53 The aim of this paper is to evaluate the relationship between changes in

54 geodynamics and relief evolution in the Cordillera Occidental in northern Peru. We infer

55 relief evolution from apatite (U-Th)/He (AHe) and fission-track (AFT) data of the CB

56 and the Cordillera Negra $(\mathrm{CN})$. We compare time-temperature inverse modeling (QTQt;

57 Gallagher, 2012) with the timing of the arrival of the Nazca Ridge at the subduction zone,

58 periods of magmatic activity, and periods of uplift.

59 GEOLOGIC AND GEODYNAMIC CONTEXT

60 Reconstructions of the timing and location of the initial Nazca Ridge subduction

61 and its subsequent southeastward migration constrain the timing of slab flattening (e.g.,

62 McNulty and Farber, 2002; Rosenbaum et al., 2005). These reconstructions are based on

63 symmetric seafloor-spreading in a hotspot reference frame, and rely on the calculation of

64 the Nazca Plate motion with respect to South America, which may contain considerable

65 errors. Rosenbaum et al. (2005) presented a regionally refined plate circuit that suggests

66 ridge subduction beginning at $15 \mathrm{Ma}$ at $10^{\circ} \mathrm{S}$ and the arrival of the Inca Plateau at the

67 trench at $5^{\circ} \mathrm{S}$ at $13 \mathrm{Ma}($ Fig. 1$)$. 
Publisher: GSA

Journal: GEOL: Geology

DOI:10.1130/G37061.1

The CB is a 14-5 Ma granitic pluton (zircon U-Pb; Mukasa, 1984; Giovanni,

69 2007) intruded into Jurassic sediments. The high summits of the CB build the footwall of

70 the CBNF, which has produced $>4500 \mathrm{~m}$ of vertical offset since $5 \mathrm{Ma}$ (Bonnot, 1984;

71 Giovanni, 2007). The Callejón de Huaylas, a 150 km long range-parallel intra-mountain

72 basin, separates the $\mathrm{CB}$ and the $\mathrm{CN}$. The 8-3 Ma Yungay ignimbrites, in the northern part

73 of the basin (Farrar and Noble, 1976; Cobbing et al., 1981; Wise and Noble, 2003), and

$745.4 \pm 0.1 \mathrm{Ma}$ ignimbrites at the base of the stratigraphy of this basin, constrain the timing

75 of basin formation in relation to CBNF activity (Giovanni et al., 2010). The CB batholith

76 and synchronous volcanic deposits indicate the last activity before the cessation of

77 magmatism (Petford and Atherton, 1992) associated with slab flattening.

78 The Cretaceous and Paleogene plutons (73-48 Ma; Beckinsale et al., 1985)

79 intruded into Jurassic sediments of the $\mathrm{CN}$ forms a plateau with summits $>5000 \mathrm{~m}$ and

$80 \quad 1-2 \mathrm{~km}$-deep valleys incised into its western flank. Some Neogene volcano-sedimentary

81 deposits cap the CN (54-15 Ma Calipuy Formation; Cobbing et al., 1981). Few studies

82 have addressed volcanism in the CN (Farrar and Noble, 1976; Myers, 1976; Noble et al.,

83 1990), and no thermochronologic data are currently available. In the CB, few AFT and

84 AHe data are available, mostly from glacial valleys along longitudinal profiles (Montario,

85 2001; Giovanni, 2007; Hodson, 2012). Thermochronological data outside of our CB and

86 CN study areas are limited (Wipf, 2006, Michalak, 2013, Eude et al., 2015), preventing

87 any regional thermal modeling. Due to the absence of thermochronologic data in the CN,

88 earlier exhumation models focused on the CBNF.

89 METHODS 
Publisher: GSA

Journal: GEOL: Geology

DOI: $10.1130 / \mathrm{G} 37061.1$

AFT and AHe thermochronology record the temperature evolution of the crust

91 from 120 to $40^{\circ} \mathrm{C}$ (e.g., Gallagher et al., 1998; Gautheron et al., 2009), which can be

92 related to local exhumation or thermal events. Although thermochronological data do not

93 allow direct quantification of surface uplift, with complementary information exhumation

94 can be interpreted to be the result of surface uplift and enhanced erosion. We determine

95 the thermal history for a vertical profile using the QTQt software, which inverts AFT

96 annealing and AHe diffusion parameters with the Markov Chain Monte Carlo method

97 (Gallagher, 2012; details on sample processing, analysis and modeling are provided in the

98 GSA data repository ${ }^{1}$ ). We use the multikinetic annealing model of Ketcham et al. (2007)

99 to model the AFT ages and track-length dispersion and the recoil damage model of

100 Gautheron et al. (2009) to model AHe ages.

101 NEW THERMOCHRONOLOGICAL DATA

102 We sampled three profiles with elevations spanning $0.9-1.9 \mathrm{~km}$, one in the CB

103 batholith ( $>10 \mathrm{~km}$ from the CBNF to avoid a tectonic exhumation signal) and two in the

$104 \mathrm{CN}$, providing 33 AFT ages, track-length measurements and single-grain AHe ages for

10523 samples (Fig. 1). The AFT ages in the CB range from $1.5 \pm 0.3-7.7 \pm 1.1 \mathrm{Ma}$ and $\mathrm{AHe}$

106 ages range from $1.9 \pm 0.2-13.7 \pm 1.4 \mathrm{Ma}$ (Fig. 1). The AHe ages are scattered and older

107 than AFT ages, raising the question of their reliability. Indeed, ${ }^{4} \mathrm{He}$ implantation from an

108 external U-Th source can generate $50 \%$ of excess He and cause age dispersion

109 (Gautheron et al., 2012). In the CN AFT ages range from 21.1 $\pm 1.3-33.2 \pm 1.9 \mathrm{Ma}$ and

110 AHe ages range from $1.9 \pm 0.2-32.6 \pm 3.3 \mathrm{Ma}$.

111 TIME TEMPERATURE INVERSION 
Publisher: GSA

Journal: GEOL: Geology

DOI: $10.1130 / \mathrm{G} 37061.1$

112 Thermal inversion of the CB age-elevation profile indicates rapid cooling at

$113 \sim 200^{\circ} \mathrm{C} / \mathrm{m}$.y. between 4.5 and $4 \mathrm{Ma}$ following batholith emplacement at high

114 temperatures (Fig. 2). This rapid cooling is bracketed by the batholith emplacement ages

115 (14-5 Ma; Mukasa, 1984; Giovanni, 2007) and AFT ages. At $\sim 4$ Ma the cooling rate

116 decreased to $25^{\circ} \mathrm{C} / \mathrm{m}$.y.

117 Inverse modeling of the northern $\mathrm{CN}$ suggests an initial cooling stage between 30

118 and $23 \mathrm{Ma}$, followed by a progressive reheating between 23 and $15 \mathrm{Ma}$ (Fig. 2). Between

$11915 \mathrm{Ma}$ and today the rocks cooled at $7^{\circ} \mathrm{C} / \mathrm{m}$.y. The southern $\mathrm{CN}$ model indicates an initial

120 cooling episode between 30 and $18 \mathrm{Ma}$, and then a 18-15 Ma heating event. From $15 \mathrm{Ma}$

121 to today the rocks recorded a cooling phase with a rate around $7^{\circ} \mathrm{C} / \mathrm{m}$.y. (Fig. 2). For both

$122 \mathrm{CN}$ profiles, the obtained Temperature-time (Tt) paths indicate slow cooling during the

123 Oligocene followed by reheating during the Early Miocene and finally monotonic cooling

124 since $\sim 15$ Ma (Fig. 2).

125 DISCUSSION

126 Middle Miocene Exhumation of the Northern Peruvian Andes

127 Both $\mathrm{CN}$ profiles indicate reheating of the crust over several million years before

$12815 \mathrm{Ma}$ and subsequent cooling. This progressive reheating likely corresponds to regional

129 heating during emplacement of the volcanic Calipuy Formation (54-15 Ma; Cobbing et

130 al., 1981). The presence of the Calipuy magmatic arc possibly increased the geothermal

131 gradient in the Cordillera Occidental.

132 The cause of the onset of exhumation recorded by the cooling phase in the $\mathrm{CN}$

133 between 15 and $0 \mathrm{Ma}$ is not straightforward. Pollen analyses constrained a maximum

134 possible elevation of $2 \mathrm{~km}$ in the Peruvian Andes before the Middle Miocene (Hoorn et 
Publisher: GSA

Journal: GEOL: Geology

DOI:10.1130/G37061.1

135 al., 2010). At that time, the $\mathrm{CN}$ formed the drainage divide (Fig. 3A; Wise and Noble,

136 2003). McLaughlin (1924) suggested that the CN Jurassic sediments, deposited near sea

137 level, were uplifted and eroded to a low relief surface (Puna surface) until $15 \mathrm{Ma}$,

138 during the Quechua 1 deformation event. This surface is presently located at $\sim 400 \mathrm{~m}$

139 a.s.1.. Late Miocene volcanic rocks (7.4 Ma, Wipf, 2006) fill a paleovalley (now

140 reincised) along the Rio Fortaleza, which has its headwaters in the CN. This morphology

141 records a change in base level indicating that some uplift and incision occurred between

14215 and 7 Ma (Farrar and Noble, 1976, Myers, 1976). Giovanni et al. (2010) showed from

$143 \delta^{18} \mathrm{O}$ analyses of paleolake deposits that high elevations in the Callejon de Huaylas basin

144 (Fig. 1) were attained by latest Miocene times. Therefore, the cooling recorded at $15 \mathrm{Ma}$

145 in the $\mathrm{CN}$ is likely related to erosion triggered by regional surface uplift. This scenario is

146 consistent with previous studies bracketing the uplift of the Western Andes of northern

147 Peru between the Early and Late Miocene (e.g., Farrar and Noble, 1976, Myers, 1976;

148 Giovanni et al., 2010; Hoorn et al., 2010).

149 Ridge Subduction, Slab Flattening and Surface Uplift

150 The initiation of exhumation at $\sim 15 \mathrm{Ma}$ in the $\mathrm{CN}$ correlates with subduction of

151 the Nazca Ridge (Fig. 3B; Rosenbaum et al., 2005). Exhumation in the CN continued

152 after initial ridge subduction and its southward migration until today (Figs. 3C, 3D). The

153 timing $(15 \mathrm{Ma})$ and location $\left(10^{\circ} \mathrm{S}\right)$ of the initial Nazca Ridge subduction proposed by

154 Rosenbaum et al. (2005) is consistent with the Middle Miocene continental shelf uplift at

155 this latitude (von Huene and Suess, 1988), with the propagation of the orogenic front

156 toward the east at $\sim 8 \mathrm{Ma}$ (Mégard, 1987), and with the shift of magmatic sources toward

157 the east from the Calipuy Formation (54-15 Ma; Cobbing et al., 1981) to the CB magmas 
Publisher: GSA

Journal: GEOL: Geology

DOI: $10.1130 / \mathrm{G} 37061.1$

158 (CB batholith, Fortaleza and Yungay ignimbrites, 14-3 Ma; Mukasa, 1984; Wise and

159 Noble, 2003; Wipf, 2006; Giovanni, 2007; Giovanni et al., 2010). Eakin et al. (2014)

160 suggested that slab flattening has an influence on the evolution of the overriding plate and

161 proposed $\sim 1000 \mathrm{~m}$ positive dynamic topography in the Cordillera Occidental after slab

162 flattening. As no important compressive phase has been documented during the Middle

163 Miocene in the Cordillera Occidental in northern Peru (Mégard, 1987), we suggest that

164 regional uplift resulted from positive dynamic topography above the flat-slab.

165 Magmatism and Exhumation in the Cordillera Blanca

166 The $\mathrm{CB}$ thermal history indicates rapid cooling $\left(200^{\circ} \mathrm{C} / \mathrm{m} . \mathrm{y}.\right)$ of the batholith

167 followed by slower cooling $\left(25^{\circ} \mathrm{C} / \mathrm{m} . \mathrm{y}\right)$ beginning $\sim 4 \mathrm{Ma}$. The rapid cooling likely

168 corresponds to the post magmatic cooling of the CB batholith; coeval exhumation is not

169 excluded. The slower cooling likely corresponds to exhumation. This cooling rate

170 suggests higher exhumation rates in the $\mathrm{CB}$ than in the $\mathrm{CN}$. Following McNulty et al.

171 (1998) and Petford and Atherton (1992), we propose that strike-slip faulting facilitated

172 the earlier stage of CB exhumation (Fig. 3C). Our data combined with previously

173 published thermochronologic data (U-Pb and Ar-Ar; Giovanni, 2007) indicate that the

$174 \mathrm{CB}$ emplacement and onset of exhumation are coeval, suggesting that the crustal

175 emplacement of low-density magma participated in the exhumation of the CB (Petford

176 and Atherton, 1992). The presence of polished granitic clasts in Pliocene sediments

177 indicates glacial erosion of the $\mathrm{CB}$ (Bonnot, 1984), placing the $\mathrm{CB}$ at elevations at least

178 in excess of $\sim 3500 \mathrm{~m}$ at this time. Finally, we suggest that magmatism and glacial

179 erosion (Fig. 3D) continued to drive the local CB uplift and exhumation in a context of

180 regional surface uplift following slab flattening. 
Publisher: GSA

Journal: GEOL: Geology

DOI:10.1130/G37061.1

The CB exhumation cannot be explained with models involving increased

182 coupling at the plate interface and shortening in the upper plate. Such models are not

183 compatible with extension related to the CBNF. The initiation of the CBNF ( 5.4 Ma;

184 Giovanni et al., 2010) is $\sim 10$ Myr after the subduction of the Nazca Ridge (15 Ma;

185 Rosenbaum et al., 2005), demonstrating that the subduction of the ridge does not control

186 extension on the CBNF and CB exhumation, as suggested by McNulty and Farber

187 (2002). Collapse models (e.g., Dalmayrac and Molnar, 1981) are in contradiction with the

188 15-0 Ma exhumation of the $\mathrm{CN}$. We suggest that the fault is accommodating the

189 differential exhumation of the two cordilleras.

190 SUMMARY

191 Thermochronological data and temperature-time history modeling, suggest

192 exhumation since $15 \mathrm{Ma}$ in the $\mathrm{CN}$. We interpret this exhumation phase as the result of

193 elevated erosion rates in response to regional surface uplift. This scenario is in agreement

194 with other studies bracketing the timing of uplift of the Cordillera Occidental between the

195 Early and Late Miocene (e.g., Hoorn et al., 2010), but contradicts models of extensional

196 or gravitational collapse of thickened crust (e.g., Dalmayrac and Molnar, 1981). We

197 propose that surface uplift in the Cordillera Occidental was driven by the Nazca Ridge

198 subduction, slab flattening, and associated magmatism (i.e., CB magmas). By

199 constraining the timing of heating and cooling of upper crustal rocks from the late

200 Oligocene to the present, this study provides new evidence linking flat subduction to the

201 topographic evolution of the northern Peruvian Andes.

202 ACKNOWLEDGMENTS 
Publisher: GSA

Journal: GEOL: Geology

DOI: $10.1130 / \mathrm{G} 37061.1$

(Investissements d'avenir - ANR10 LABX56), ECOS-

NORD/COLCIENCIAS/ICETEX and SMINGUE. We thank the SERNAMP for

allowing sampling in the CB, and F. Coeur, F. Senebier, E. Hardwick, M. Balvay, R.

Pinna-Jamme, K. Hodson and M. Michalak for sample preparation. We thank C.

Lithgow and two anonymous reviewers for their constructive reviews.

210 Barazangi, M., and Isacks, B.L., 1976, Spatial distribution of earthquakes and subduction

211 of the Nazca plate beneath South America: Geology, v. 4, p. 686-692, doi:10.1130/0091-7613(1976)4<686:SDOEAS>2.0.CO;2.

213 Beckinsale, R.D., Sanchez-Fernandez, A.W., Brook, M., Cobbing, E.J., Taylor, W.P., and 214 Moore, N.D., 1985. Rb-Sr whole-rock isochron and K-Ar age determinations for the 215 Coastal Batholith of Peru, in Pitcher, W.S., and Atherton, M.P., eds., Magmatism at 216 a Plate Edge: The Peruvian Andes: Glasgow, Blackie, p. 177-202.

217 Bonnot, D., 1984, Néotectonique et tectonique active de la Cordillère Blanche et du

218 Callejon de Huaylas (Andes nord-péruviennes) [Thesis (unpublished)]: Centre 219 d'Orsay, Université de Paris-Sud, p. 1-202.

220 Cobbing, J., Pitcher, W., Baldock, J., Taylor, W., McCourt, W., and Snelling, N.J., 1981,

221 Estudio geológico de la Cordillera Occidental del norte del Perú: Instituto Geologico

222 Minero y Metalurgico, Serie D. Estudios Especiales, v. 10, no. D., p. 1-252

223 Dalmayrac, B., and Molnar, P., 1981, Parallel thrust and normal faulting in Peru and

224 constraints on the state of stress: Earth and Planetary Science Letters, v. 55, p. 473-

225 481, doi:10.1016/0012-821X(81)90174-6. 
Publisher: GSA

Journal: GEOL: Geology

DOI: $10.1130 / \mathrm{G} 37061.1$

226 Eakin, C.M., Lithgow-Bertelloni, C., and Dávila, F.M., 2014, Influence of Peruvian flat-

227 subduction dynamics on the evolution of western Amazonia: Earth and Planetary

228 Science Letters, v. 404, p. 250-260, doi:10.1016/j.epsl.2014.07.027.

229 Eude, A., Roddaz, M., Brichau, S., Brusset, S., Calderon, Y., Baby, P., and Soula, J.C.,

2302015 , Controls on timing of exhumation and deformation in the northern Peruvian

231 eastern Andean wedge as inferred from low-temperature thermochronology and

232 balanced cross section: Tectonics, v. 34, p. 715-730, doi:10.1002/2014TC003641.

233 Farrar, E., and Noble, D.C., 1976, Timing of late Tertiary deformation in the Andes of

234 Peru: Geological Society of America Bulletin, v. 87, p. 1247-1250,

235 doi:10.1130/0016-7606(1976)87<1247:TOLTDI>2.0.CO;2.

236 Gallagher, K., 2012, Transdimensional inverse thermal history modeling for quantitative

237 thermochronology: Journal of Geophysical Research, v. 117, B02408,

238 doi:10.1029/2011JB008825.

239 Gallagher, K., Brown, R., and Johnson, C., 1998, Fission track analysis and its

240 applications to geological problems: Annual Review of Earth and Planetary

241 Sciences, v. 26, no. 1, p. 519-572, doi:10.1146/annurev.earth.26.1.519.

242 Gautheron, C., Tassan-Got, L., Ketcham, R.A., and Dobson, K.J., 2012, Accounting for

243 long alpha-particle stopping distances in (U-Th-Sm)/He geochronology: 3D

244 modeling of diffusion, zoning, implantation, and abrasion: Geochimica et

245 Cosmochimica Acta, v. 96, p. 44-56, doi:10.1016/j.gca.2012.08.016.

246 Gautheron, C., Tassan-Got, L., Barbarand, J., and Pagel, M., 2009, Effect of alpha-

247 damage annealing on apatite (U-Th)/He thermochronology: Chemical Geology,

248 v. 266, p. 157-170, doi:10.1016/j.chemgeo.2009.06.001. 
Publisher: GSA

Journal: GEOL: Geology

DOI:10.1130/G37061.1

249 Giovanni, M.K., 2007, Tectonic and Thermal Evolution of the Cordillera Blanca

250 Detachment System, Peruvian Andes: Implication for Normal Faulting in a

251 Contractionnal Orogen [Thesis (unpublished)]: Los Angeles, University of

252 California-Los Angeles, p. 1-255.

253 Giovanni, M.K., Horton, B.K., Garzione, C.N., McNulty, B., and Grove, M., 2010,

254 Extensional basin evolution in the Cordillera Blanca, Peru: Stratigraphic and isotopic

255 records of detachment faulting and orogenic collapse in the Andean hinterland:

256 Tectonics, v. 29, TC6007, doi:10.1029/2010TC002666.

257 Gutscher, M.A., Olivet, J.L., Aslanian, D., Eissen, J.P., and Maury, R., 1999, The "lost

258 Inca Plateau": cause of flat subduction beneath Peru?: Earth and Planetary Science

259 Letters, v. 171, p. 335-341, doi:10.1016/S0012-821X(99)00153-3.

260 Hodson, K.R., 2012, Morphology, exhumation, and Holocene erosion rates from a

261 tropical glaciated mountain range: The Cordillera Blanca, Peru [Thesis

262 (unpublished)]: Montréal, McGill University, p. 1-94.

263 Hoorn, C., et al., 2010, Amazonia Through Time: Andean Uplift, Climate Change,

264 Landscape Evolution, and Biodiversity: Science, v. 330, no. 6006, p. 927-931,

265 doi:10.1126/science.1194585.

266 von Huene, R., and Suess, E., 1988, Ocean Drilling Program Leg 112, Peru continental

267 margin: Part 1, Tectonic History: Geology, v. 16, p. 934-938, doi: 10.1130/0091-

$268 \quad 7613(1988) 016<0934:$ ODPLPC $>2.3 . C O ; 2$.

269 INGEMMET (El Instituto Geológico Minero y Metalúrgic), 1999, Mapa geológico del

270 Perú: Peru, Instituto Geológico, Minero y Metalúrgico, Sector Energía y Minas,

$271 \quad 1: 1,000,000$.

Page 12 of 16 
Publisher: GSA

Journal: GEOL: Geology

DOI:10.1130/G37061.1

272 Ketcham, R.A., Carter, A., Donelick, R.A., Barbarand, J., and Hurford, A.J., 2007,

273 Improved measurement of fission-track annealing in apatite using c-axis projection:

274 The American Mineralogist, v. 92, p. 789-798, doi:10.2138/am.2007.2280.

275 McLaughlin, D.H., 1924, Geology and physiography of the Peruvian Cordillera,

276 departments of Junin and Lima: Geological Society of America Bulletin, v. 35,

277 p. 591-632, doi:10.1130/GSAB-35-591.

278 McNulty, B.A., and Farber, D.L., 2002, Active detachment faulting above the Peruvian

279 flat slab: Geology, v. 30, p. 567-570, doi:10.1130/0091-

$280 \quad 7613(2002) 030<0567:$ ADFATP $>2.0 . C O ; 2$.

281 McNulty, B.A., Farber, D.L., Wallace, G.S., Lopez, R., and Palacios, O., 1998, Role of

282 plate kinematics and plate-slip-vector partitioning in continental magmatic arcs:

283 Evidence from the Cordillera Blanca, Peru: Geology, v. 26, p. 827-830,

284

doi:10.1130/0091-7613(1998)026<0827:ROPKAP>2.3.CO;2.

285 Mégard, F., 1987, Structure and evolution of the Peruvian Andes: The anatomy of

286 mountain ranges, in Schaer, J.P., and Rodgers J., eds., The Anatomy of Mountain

287 Ranges: Princeton, New Jersey, Princeton University Press, p. 179-210.

288 Michalak, M.J., 2013, Exhumation of the Peruvian Andes: Insights from Mineral

289 Chronometers [Ph.D. thesis]: Santa Cruz, California, University of California, p. 1$290 \quad 166$

291 Montario, M.J., 2001, Exhumation of the Cordillera Blanca, Northern Peru, based on

292 apatite fission track analysis [Thesis (unpublished)]: Schenectady, New York, Union

293 College, Department of Geology, p. 1-12. 
Publisher: GSA

Journal: GEOL: Geology

DOI: $10.1130 / \mathrm{G} 37061.1$

294 Mukasa, S.B., 1984, Comparative Pb isotope systematics and zircon U-Pb geochronology

295 for the Coastal San Nicolas and Cordillera Blanca batholiths, Peru [Thesis

296 (unpublished)]: Santa Barbara, University of California-Santa Barbara, p. 1-362.

297 Myers, J.S., 1976, Erosion surfaces and ignimbrite eruption, measures of Andean uplift in 298 northern Peru: Geological Journal, v. 11, p. 29-44, doi:10.1002/gj.3350110104.

299 Noble, D.C., McKee, E.H., Mourier, T., and Mégard, F., 1990, Cenozoic stratigraphy,

300 magmatic activity, compressive deformation, and uplift in northern Peru: Geological

$301 \quad$ Society of America Bulletin, v. 102, p. 1105-1113, doi:10.1130/0016-

$302 \quad$ 7606(1990)102<1105:CSMACD>2.3.CO;2.

303 Petford, N., and Atherton, M.P., 1992, Granitoid emplacement and deformation along a

304 major crustal lineament: the Cordillera Blanca, Peru: Tectonophysics, v. 205, p. 171305 185, doi:10.1016/0040-1951(92)90425-6.

306 Ramos, V.A., and Folguera, A., 2009, Andean flat-slab subduction through time:

307 Geological Society of London, Special Publications, v. 327, p. 31-54,

308 doi:10.1144/SP327.3.

309 Rosenbaum, G., Giles, D., Saxon, M., Betts, P.G., Weinberg, R.F., and Duboz, C., 2005,

310 Subduction of the Nazca Ridge and the Inca Plateau: Insights into the formation of

311 ore deposits in Peru: Earth and Planetary Science Letters, v. 239, p. 18-32,

312 doi:10.1016/j.epsl.2005.08.003.

313 Wipf, M., 2006, Evolution of the Western Cordillera and Coastal Margin of Peru:

314 Evidence from low-temperature Thermochronology and Geomorphology: Zürich, 315 Swiss Federal Institute of Technology, p. 1-163. 
Publisher: GSA

Journal: GEOL: Geology

DOI: $10.1130 / \mathrm{G} 37061.1$

316 Wise, J.M., and Noble, D.C., 2003, Geomorphic evolution of the Cordillera Blanca,

317 Northern Peru: Boletín de la Sociedad Geológica del Perú, v. 96, p. 1-21.

\section{FIGURE CAPTIONS}

319 Figure 1. A) Study area location within the Peruvian flat-slab and the South America

320 Pacific margin (modified after Ramos and Folguera, 2009). The respective positions of

321 the Nazca Ridge (NR) at $\sim 15 \mathrm{Ma}, 0 \mathrm{Ma}$; and of the Inca plateau (IP) at $\sim 13 \mathrm{Ma}$

322 (Rosenbaum et al., 2005) are represented in red. B) Geological map of the Cordillera

323 Occidental (northern Peru) showing AFT ages (red) and AHe ages (blue) (modified from

324 INGEMMET geologic map of Ancash; INGEMMET, 1999.

326 Figure 2. Age-elevation plots and Temperature-time (Tt) paths predicted for

327 thermochronological ages using Gautheron et al. (2009) He diffusion model. A-C) Age-

328 elevation plots showing AFT ages (red), mean track length (MTL; yellow) and AHe ages

329 (blue), ages predicted by the thermal history are plotted in pastel colors. Northern

330 Cordillera Negra (CN) profile (A), southern CN profile (B), and Cordillera Blanca (CB)

331 profile (C). D-F) Tt paths for northern/southern CN, and CB profiles. Each line represents

332 the Tt path of a sample; red line represents the path of the lowest elevation sample and

333 blue line the highest, pastel shading represent uncertainties.

335 Figure 3. Block diagrams showing the uplift history and paleogeography of the Cordillera

336 Occidental in northern Peru. Diagrams represent surface uplift (bold arrow), volcanism

337 (black triangle), partial melting (red droplet), faults (dotted and continuous black lines),

338 drainage network, and the CB batholith. A) The Calipuy Formation emplaces in the $\mathrm{CN}$ 
Publisher: GSA

Journal: GEOL: Geology

DOI: $10.1130 / \mathrm{G} 37061.1$

339 above a "normal" subduction (54-15 Ma). B) Subduction of the NR, slab flattening, and

340 corresponding surface uplift in the $\mathrm{CN}$ at $15 \mathrm{Ma}$. C) During the slab flattening,

341 magmatism shutdowns in the $\mathrm{CN}$ and moves eastward. The $\mathrm{CB}$ batholith emplaces at

342 depth and is exhumed in a strike-slip context. D) The CBNF accommodates the recent

343 exhumation of the $\mathrm{CB}$ resulting in modern elevations $>6 \mathrm{~km}$.

344

$345{ }^{1}$ GSA Data Repository item 2015xxx, $\mathrm{xxxxxxx}$, is available online at

346 www.geosociety.org/pubs/ft2015.htm, or on request from editing@geosociety.org or

347 Documents Secretary, GSA, P.O. Box 9140, Boulder, CO 80301, USA. 


\section{$78^{\circ} 00^{\prime} \mathrm{W}$}

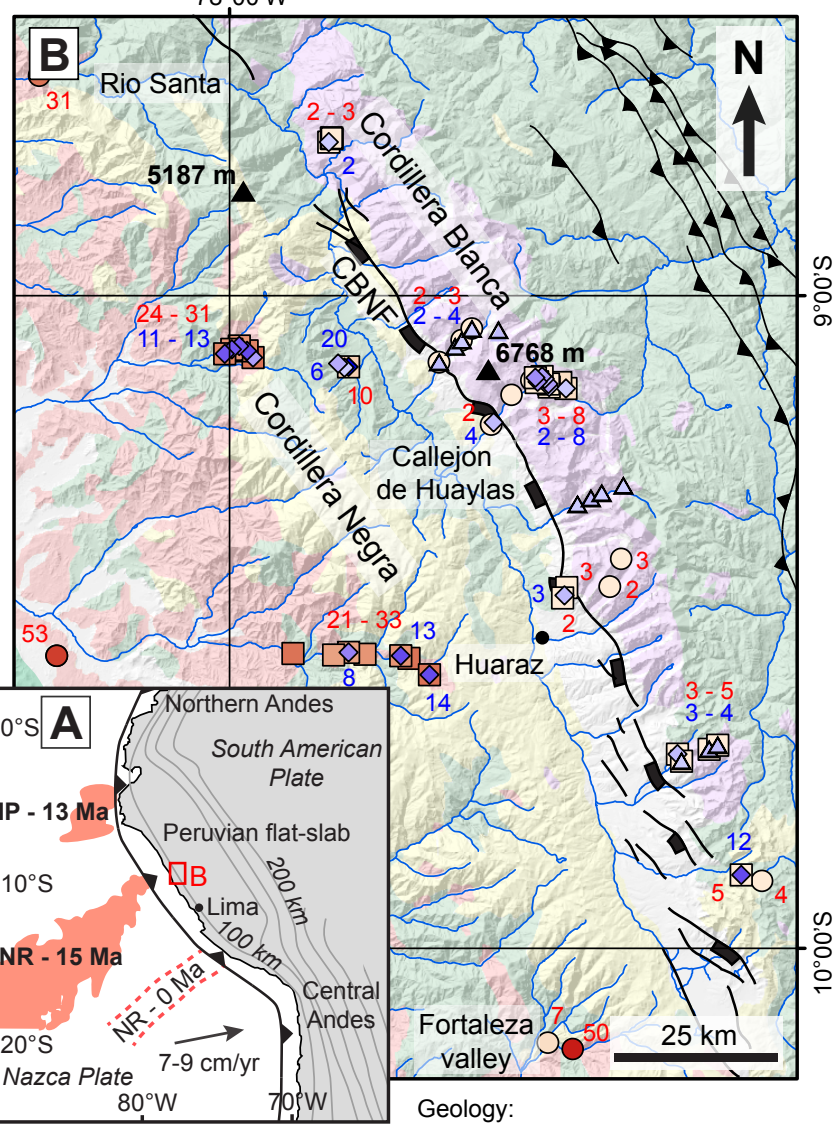

Thermochronological data:

$\mathrm{AHe}$ :

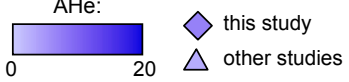

AFT:

$\square$ this study

other studies
Quaternary sedimentary deposits

Neogene granodiorite

Neogene volcano-sedimentary deposits

Cretaceous intrusives

Jurassic and Cretaceous sediments

$1 \square$ Fault, normal fault, thrust fault 
MTL $(\mu \mathrm{m}) 810121416$
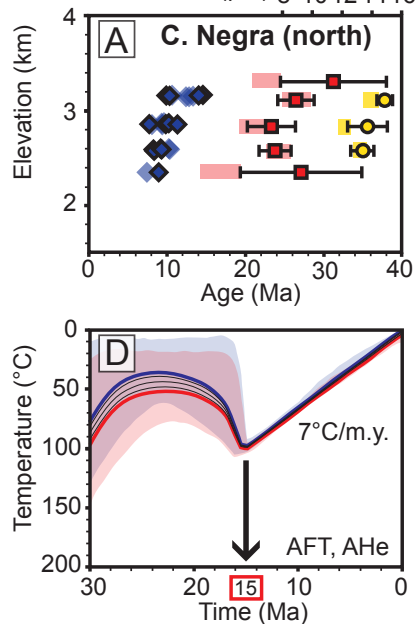

MTL $(\mu \mathrm{m}) 810121416$
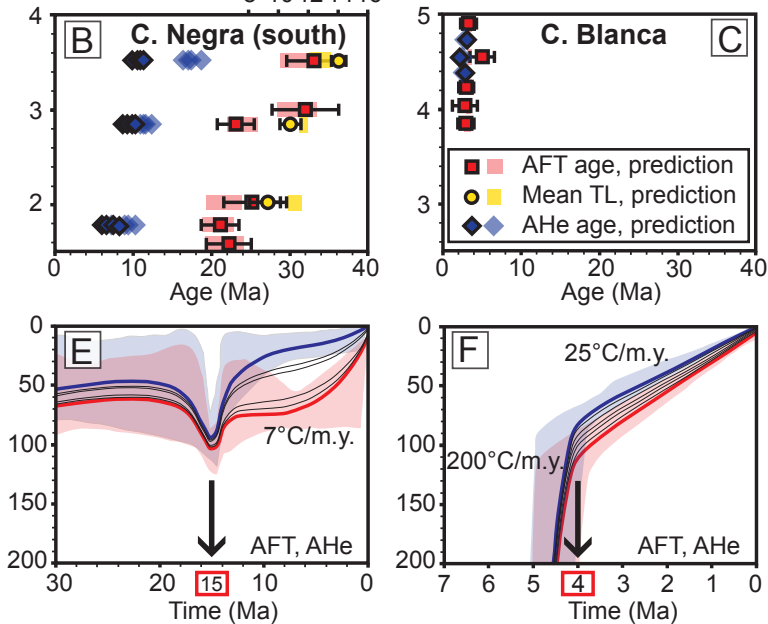

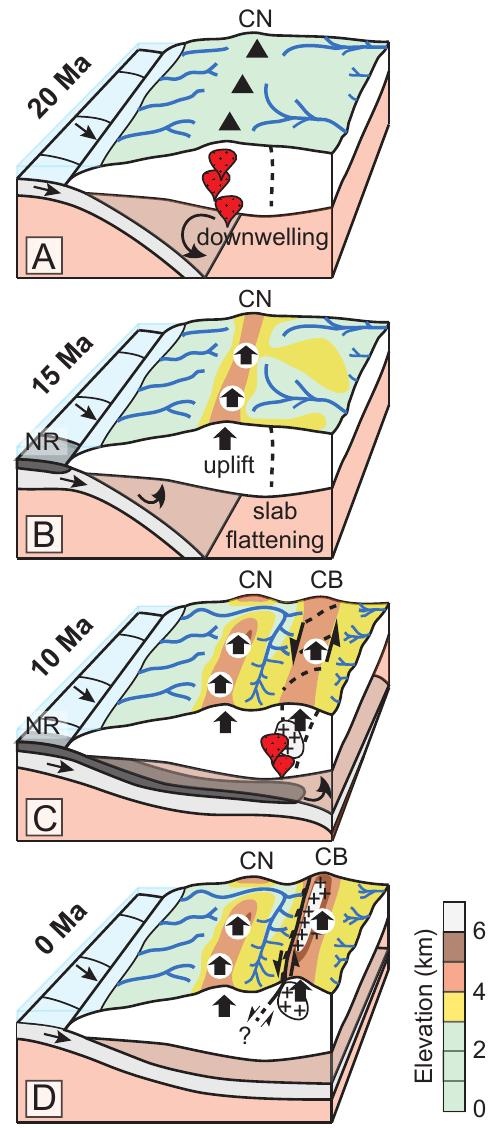